PRINT ISSN 1119-8362

Electronic ISSN 1119-8362
Full-text Available Online at https://www.ajol.info/index.php/jasem http://ww.bioline.org.br/ja

\title{
Habitats of antlions larvae (Neuroptera: Myrmeleontidae) in the Sudano-Guinean and Sudano-Sahelian zones of Cameroon
}

\author{
*BAKOIDI, A; ISMAILA, D; MAOGÉ, J; NGAMO-TINKEU, LS \\ Department of Biological Sciences, Faculty of Science, University of Ngaoundéré, Cameroon. P O Box 454 Ngaoundéré Cameroon \\ * Corresponding Author Email: bakoidiantoine@yahoo.fr; Tel: + 237690805055
}

\begin{abstract}
Antlions (Insecta: Neuroptera) are flying insect associated with sunny weather at adult stage. During larval stage, xerophilous insects they are familiar to arid soils with critical temperature, hygrometry and luminosity. These 3 climatic parameters are used to discriminate among larval habitats of antlions in the Soudano Guinean and Soudano Sahelian Savannah of Cameroon. Investigations made during 3 years from 2015 to 2018 , consisted in survey of larvae's funnels. At the level of each active pit-traps, the 3 parameters were recorded during the whole dry season. Analysis of data computerised pointed out that larvae of Cueta bourborni Navas 1935, and those of Cueta sp, are frequent within sites that are warm $\left(40.57 \pm 0.64^{\circ} \mathrm{C}\right.$ to $\left.52.14 \pm 4.08^{\circ} \mathrm{C}\right)$; dry $(10.91 \pm 0.82$ $16.81 \pm 2.74 \% \mathrm{rh})$ and lighted $(94380.2 \pm 16109.4 \mathrm{lux})$ habitats. On the other hand, larvae of Myrmeleon quinquemaculatus Hagen 1853 are associated with sites that are: humid (75.46 $\pm 4.50 \%$ RH), cloudy (448.232 \pm 300 . 491 lux $)$ with tendency to moist $\left(22.11 \pm 0.88^{\circ} \mathrm{C}\right.$ to $\left.28.10 \pm 2.14^{\circ} \mathrm{C}\right)$. Presence of $C$. bourbonni sometimes in the moisty Soudano Guinean zone could only indicate episode of warming.
\end{abstract}

DOI: https://dx.doi.org/10.4314/jasem.v24i4.18

Copyright: Copyright $(\mathcal{C} 2020$ Bakodi et al. This is an open access article distributed under the Creative Commons Attribution License (CCL), which permits unrestricted use, distribution, and reproduction in any medium, provided the original work is properly cited.

Dates: Received: 11 February 2020; Revised: 14 March 2020; Accepted: 22 March 2020

Keywords. Antlions habitats, global warming, temperature, luminosity, Hygrometry.

Habitat selection is the process by which organisms distinguish and choose among several sites of different qualities, the one that is ideal for their survival because it provides them with the highest fitness gain (Clobert et al., 2012). At the population level, this habitat choice significantly affects the way individuals are distributed among habitats, which in turn influences population dynamics (Bowler and Benton, 2005). To assess habitat quality, animals take into account various biotic and abiotic factors, particularly resource availability and habitat structure (Dubois et al., 2009). Antlions larvae prefer a specific micro-habitat on fine sand or soft soil (Scharf et al., 2011). They are sessile and their mobility being mostly reduced to walking backwards over very short distances to hide (Ngamo et al., 2010; Ngamo et al., 2014). Larvae are inferred from the site chosen by the female at the time of oviposition (Ngamo et al., 2016). Site selection is thus dictated by habitat characteristics such as shade (Scharf et al., 2008a), photoperiod (Scharf et al., 2008b), substrate moisture (Morrison, 2004), temperature (Bakoidi et al., 2018), disturbance (Barkae et al., 2010), substrate particle size, substrate depth and hardness (Klokocovnik et al., 2012), substrate density (Devetak et al., 2012), prey availability and abundance (Maogé et al., 2014). Larval habitats in forested areas, except in
Mediterranean regions are distinguished by two major characteristics: open (unprotected from rain, direct sunlight or any illumination) (Barkae et al., 2012), and protected or covered (protected from rain, disturbance, direct sunlight or any illumination) (Abraham, 2006; Scharf et al., 2008b; Adar et al., 2016; Klokocovnik et al., 2016). However, whether or not they are open to sun and rain is not sufficient to discriminate between the different habitats of these insects as they are very sensitive to ecological disturbance. Climatic factors may further specify the characteristics of habitats that best favour the development of antlion larvae to the point that they are bio-indicators. The objective of this work is to provide more specifications in the characterization of antlions larval habitats using abiotic characteristics (temperature, relative humidity, light) that have an impact on their survival. Current events in recent years cite global warming as a threat to the survival of humanity. Research on life forms or behaviours resilient to these harsh conditions is interesting in this context. The aim is to discover forms of life that are resistant to extreme conditions for mankind.

\section{MATERIALS AND METHODS}

Presentation of the study area: The sampling site extends from the Adamawa highlands to the Chad

*Corresponding Author Email: bakoidiantoine@yahoo.fr; Tel: + 237690805055 
lake. It includes the moist savannahs of the Adamawa Region, the Benoue lowlands and the Logone Plains and Mandaras highlands in sahelo Sahelian zone with extreme drought, 2 agro-ecological zones are concerned.

The Guinean High Savannah zone, which covers most of the Adamawa Plateau, is characterized by a humid climate with an average of $1000 \mathrm{~mm}$ of rainfall per year. The wet season extends from April to October with maximum rainfall between August-September (Djoufack-Manetsa et al., 2011). The dry season lasts between four and five months, with an average annual temperature of $28^{\circ} \mathrm{C}$ and a temperature difference of $6^{\circ} \mathrm{C}$ (Tchotsoua and Gonne, 2010). In this zone, antlions larval collection and recordings of climatic parameters were carried out in Ngaoundéré and its surroundings.

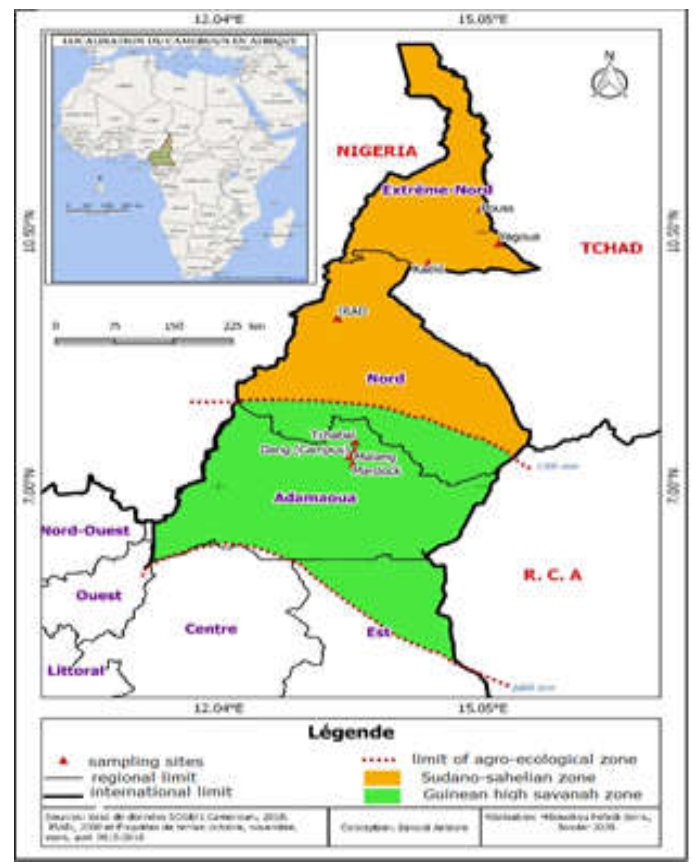

Fig. 1. Location of sampling sites of antlions at the larval stages at the beginning of the dry season in northern Cameroon.

The Sudano-Sahelian zone with a semi-arid climate covering the Far North and North Regions. It is characterized by a long dry season ( 9 months) and a short rainy season ( 3 months). It receives an average rainfall of between 400 and 1,200 $\mathrm{mm} /$ year and has a great diversity of soils. The highest temperatures are observed in the dry season (over $40^{\circ} \mathrm{C}$ in March and April) (Fotsing, 2009). The relative humidity of the air is between 30 and $35 \%$ and the further north one goes the harsher the climate becomes. The following localities: Garoua, Kaélé, Yagoua and Pouss were chosen for the collection of antlions larvae and the recording of climatic parameters at the level of active pits.

Habitat characterisation and antlions larval population dynamics: Observations of antlions pits were made on the University of Ngaoundéré Campus site in the Sudano-Guinean zone on a weekly basis for two years, 2016 and 2017 in order to note the appearance of the first pits at early dry season and disappearance of the last ones at the return of the rains of each year and to establish the dynamics of the larval pits. Thus, once a week the presence of pits was noted and the numbers of pits recorded whether under trees, near buildings or in open areas over an area of $25 \mathrm{~m}^{2}$. During the period of high density, under trees (March: temperature $35^{\circ} \mathrm{C}$ RH $27 \%$ and April: temperature $34^{\circ} \mathrm{C}$; RH $36 \%$ ) and closer to buildings or under wet covered habitat (every month), pits were counted on four $25 \mathrm{~m}^{2}$ grids for each sampling site.

On the different sites in the Sahelian and Guinean zones, at the level of each active pit within the chosen $25 \mathrm{~cm}^{2}$ area, the ground climatic parameters were recorded during the months of high abundance. For the whole zone, continuous measurements of climatic data were made using a $\mathrm{HOBO}$ onset $\mathrm{H} 8$ data logger from 2015 to 2018 .

Climatic parameters recorded at the level of the ground at each sampling were analysed by one-way ANOVA test. In the post test a Duncan procedure was proceeding to access the less significant difference among means observed.

Rearing of collected larvae in laboratory: The antlions larvae extracted from the active pits brought back to the laboratory are raised in plastic cups filled to a third with sea sand sieved to 500 microns placed in rearing cages provide with temperature control monitor. Rearing was made in cages monitored at $22^{\circ} \mathrm{C}, 27^{\circ} \mathrm{C}$, $40^{\circ} \mathrm{C}$. All observed larvae were fed ad libitum on third instar larvae of Tribolium castaneum Herbst 1797 (Coleoptera: Tenebrionidae). Growing of larvae was followed till it turns into a cocoon. The cocoon is observed separately till adult emerges.

\section{RESULTS AND DISCUSSION}

Pits traps Fluctuation and Characterisation of Antlions Larval Habitats: (a). Seasonal Fluctuation in pits of Antlions Larvae: The variation in the number of pits in different habitats in the Study Area during the two years of observations shows that the number of pits within a single habitat varies from month to month (Figure 2). The covered and humid habitat is the only one where pits are observed all year round with a high abundance in October at temperatures around $30^{\circ} \mathrm{C}$; 
relative humidity $57.6 \%$, light intensity 50698 lux and November with temperature $34^{\circ} \mathrm{C}$, relative humidity 40\%, light intensity 50698 lux, then March and April with respectively $35^{\circ} \mathrm{C}$ and $34^{\circ} \mathrm{C}$ temperature and $36.57 \%$ and $39 \%$ relative humidity and 58190 lux and 69228 lux light intensity. The overcast and dry environment, on the other hand, only presents the pits of the antlions' larvae in the dry season from February to April with their peak of abundance in March. The dry open environment is occupied by larvae at the beginning of the dry season from November to January with average temperatures of and very rarely in February and March (2016). On the other hand, larval activity in covered and dry areas occurs from February to April with abundance in March and April depending on the year. The dynamics of pits varied according to the environment or habitat and period of capture. The most important collections took place in the second half of the dry season: March, 647 captures (temperature, $35^{\circ} \mathrm{C} \mathrm{RH}, 27 \%$ ) and April 254 captures (temperature $34^{\circ} \mathrm{C}$; RH $36 \%$ ) Open-air collections were only made at the beginning of the dry season and during the hottest years (average temperature $37^{\circ} \mathrm{C} \mathrm{\&}$ average RH 30\%).

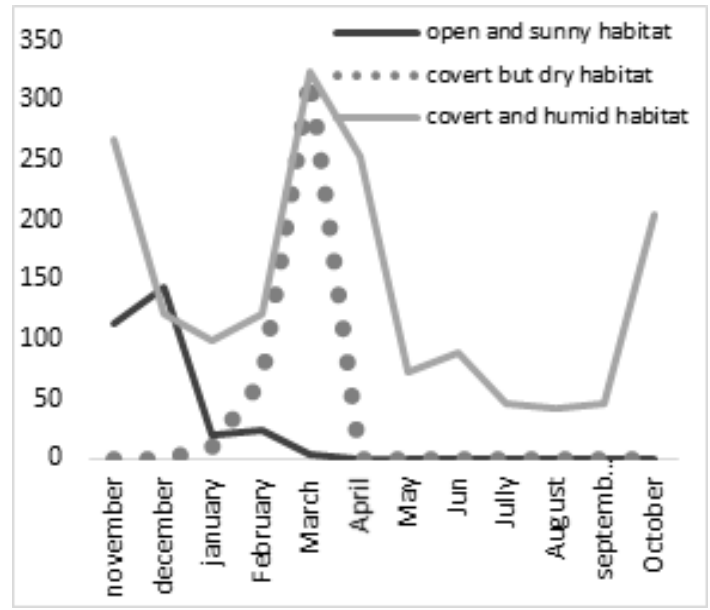

Fig 2. Mean of monthly fluctuation of the amount of active funnels of antlion depending on the type of habitat in northern Cameroun during the years 2016 abd 2017

Covered collections took place throughout the year with the lowest collections during the wettest periods (August; temperature, $20^{\circ} \mathrm{C} \mathrm{RH}, 81 \%$ ). The most important collections are made after the unfavourable periods (end of dry season and end of wet season). The absence of pits in open and covered areas under the trees from May onwards can also be explained by the return of rain which would influence the construction of the pits. This is related to the work of Ngamo et al., (2016) and Scharf et al., (2009) who showed that low temperatures and rainfall slow down the development of antlion larvae. Antlions larvae are more abundant during the warmest months including March $35^{\circ} \mathrm{C}$ and $27 \% \mathrm{RH}$ and April $34^{\circ} \mathrm{C}$ and $36 \% \mathrm{RH}$. Under permanent shadows there are larvae present all year round that are more tolerant of wet conditions.

(b) Influence of hygrometry on the occurrence of pit building antlion larvae: Hygrometry is an important climatic factor in characterising the habitat of antlions larvae. Larval activity, as a function of hygrometry varies from one agro-ecological zone to another and also from one habitat to another (Figure $3 a$ and $b$ ). In the Sudano-Guinean zone, larvae in covered and cool environments are active from $85 \% \mathrm{RH}$ and can withstand dry conditions up to $25 \% \mathrm{RH}$ (Figure $3 \mathrm{a}$ ).

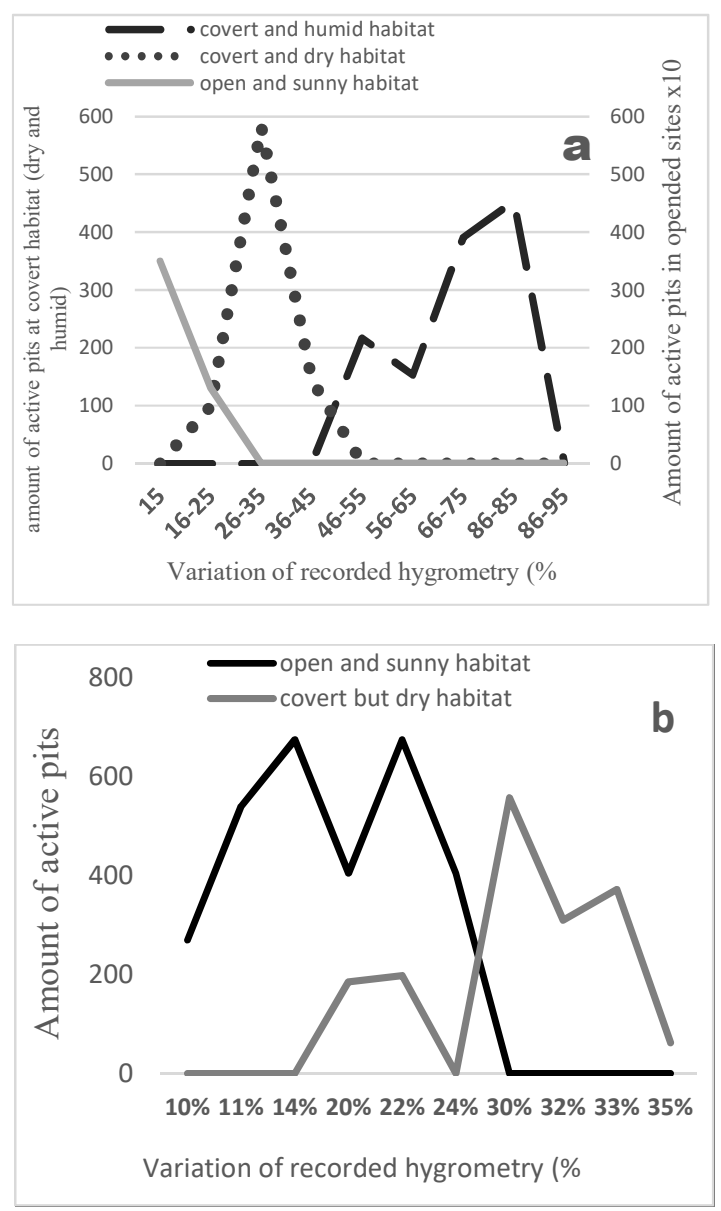

Fig 3. Variation of the amount of pit building antlion larvae in activity within different habitats inrelationship with the variation of the hygrometry in the Sudano-Guinean (a) and Sudano-Sahelian (b) zones.

The peak of their activity is observed between 26 and $35 \% \mathrm{RH}$ at which more than $55 \%$ of the larvae are active. Covered and wetland species are very active 
from $55 \%$ RH with the optimum activity between $75 \%$ and $85 \%$. In open habitats, antlions larvae are only present at very dry periods. Peak activity is observed at $15 \% \mathrm{RH}$, there is activity at $25 \% \mathrm{RH}$ but less. In the Sudano-Sahelian zone, larvae in open environments are active at $24 \% \mathrm{RH}$ and can withstand dry conditions up to $10 \%$ RH (Figure $3 \mathrm{~b}$ ). Peaks in their activity are observed at $14 \%, 22 \%$ and $11 \% \mathrm{RH}$ values at which more than $70 \%$ of larval activity has been observed. The activity curve of the species in the covered environment shows that larval activity can range from $20 \%$ to $35 \% \mathrm{RH}$ and are very active from $30 \% \mathrm{RH}$ and moderately active at $22 \%$ and $33 \% \mathrm{RH}$.

(c) Influence of the temperature on the occurrence of pit building antlion larvae: Recording of ground temperature at active pits in the Sudano-Guinean zone shows that larvae are active from $18^{\circ} \mathrm{C}$ to $42^{\circ} \mathrm{C}$, while in the Sudano-Sahelian zone activity ranges from $31^{\circ} \mathrm{C}$ to $51^{\circ} \mathrm{C}$ (Figure 4 ).

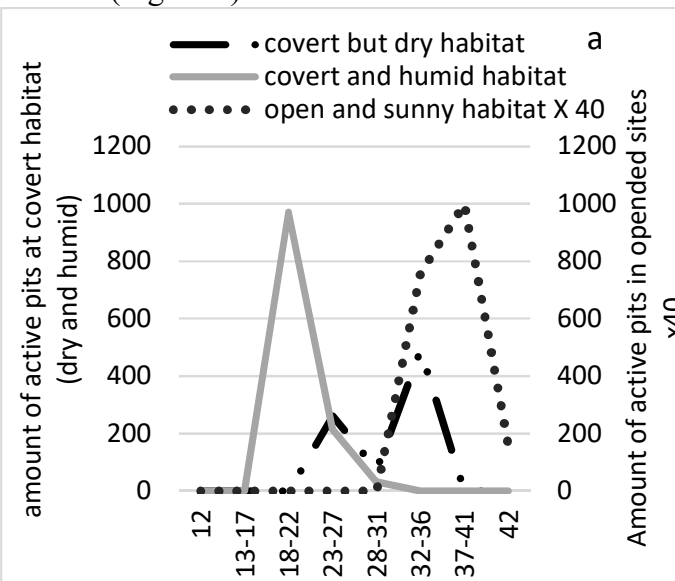

Variation in the temperatures at which larvae are active $\left({ }^{\circ} \mathrm{C}\right)$

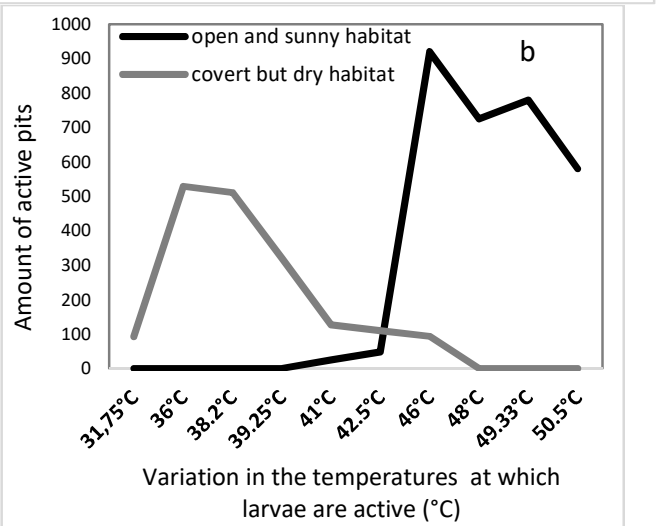

Fig 4. Variation of the amount of pit building antlion larvae in activity within different habitats in relationship with the variation of the temperature in the Sudano-Guinean (a) and Sudano-Sahelian (b) zones.
In the Sudano-Guinean zone, all larvae active in open habitats were active in the range $32^{\circ} \mathrm{C}$ to $42^{\circ} \mathrm{C}$, whereas in cool overcast areas larvae are active from $27^{\circ} \mathrm{C}$ to $36^{\circ} \mathrm{C}$. Larvae active at cool temperatures were abundant at $22^{\circ} \mathrm{C}$ where more than $60 \%$ of observations were made. (Figure.4a). In the SudanoSahelian zone, larvae from the overcast environment are active at moderately warm temperatures from $31^{\circ} \mathrm{C}$ to $46^{\circ} \mathrm{C}$ with the optimum activity ranging from $36^{\circ} \mathrm{C}$ to $39^{\circ} \mathrm{C}$, whereas larvae from warm open habitats are active at high temperatures ranging from $41^{\circ} \mathrm{C}$ to $50.5^{\circ} \mathrm{C}$, with optimum maintenance activity at $46^{\circ} \mathrm{C}$. Larvae active at cool temperatures were abundant at $36^{\circ} \mathrm{C}$ and $38^{\circ} \mathrm{C}$ where more than $60 \%$ of observations were made (Figure $4 b$ ).

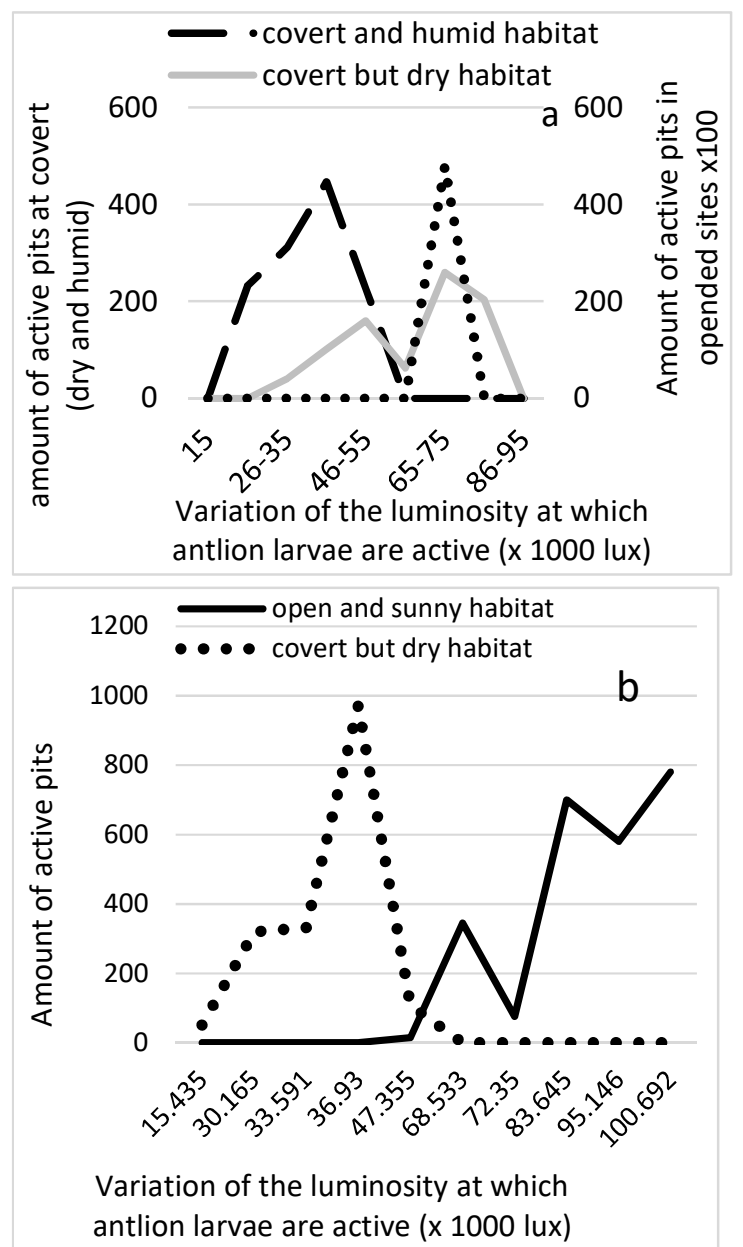

Fig 5. Variation of the amount of pit building antlion larvae in the different habitats in relationship with the variation of the luminosity in the Sudano-Guinean (a) and Sudano-Sahelian (b) zones.

(d) Influence of luminosity on the occurrence of pit building antlion larvae: Luminosity that affects the 
activities of antlion larvae. Figure 5 presents the activity of antlion larvae as a function of light intensity and shows that activities are observed from $15 \times 1000$ lux up to $106.592 \times 1000$ lux. In the Sudano-Guinean zone, larval activity shows two peaks of abundance: a peak at $35 \times 1000$ lux corresponding to the lowest values and a peak of 65 to $75 \times 1000$ lux corresponding to the highest values. Larvae in covered habitats have two peaks of activity at $35 \times 1000$ lux, which is the highest, and a second peak of activity at $65 \times 1000$ lux; species in open habitats have a single peak at $75 \times 1000$ lux (Figure5a). In the Sudano-Sahelian zone, larval activities show two peaks of abundance: a peak at $36.930 \times 1000$ lux corresponding to the lowest values and the peak from 83.645 to $106.592 \times 1000$ lux corresponding to the highest values (Figure 5b). Larvae from open habitats have two peaks of activity at $106.592 \times 1000$ lux which is the highest and a second one at $83.645 \times 1000$ lux; species from covered habitats, on the other hand, have a single peak at $36.930 x 10001 u x$

(e)Characterization of habitats and diversity of antlions larvae: The recordings and analysis of climatic parameters such as relative humidity (Table 1) at the pits of antlions allow us to distinguish between two types of habitat: open and covered environments. Within the covered habitats, temperature and luminosity recordings made it possible to separate these environments into wet and dry habitats. The analysis of variance shows that the difference is significant for each parameter recorded (Temperature: $\mathrm{F}=273.82 * * *$ and $\mathrm{ndl}=4: 28$; for Relative humidity: $\mathrm{F}=80.35 * * *$ and $\mathrm{ndl}=4$ : 282 ; for light intensity: $\mathrm{F}=282.81 * * *$ and $\mathrm{ndl}=4$ : 282). Duncan's test separates them into 4 classes for temperature, 3 classes for relative humidity and 4 classes for light intensity.

Table 1. Characteristics of antlion larval habitats and larval diversity.

\begin{tabular}{|c|c|c|c|c|c|}
\hline Domain & (900 to 1 & $\begin{array}{l}\text { Guinean } \\
00 \mathrm{~mm} \text { rainfall } / \mathrm{y}\end{array}$ & & $\begin{array}{r}\mathbf{S a} \\
(400 \text { à } 1000\end{array}$ & $\begin{array}{l}\text { elian } \\
\text { m rainfall/year) }\end{array}$ \\
\hline $\begin{array}{l}\text { habitat } \\
\text { (adults obtained) }\end{array}$ & $\begin{array}{l}\text { Covert Humid } \\
\text { (79) }\end{array}$ & $\begin{array}{l}\text { Covert dry } \\
(53)\end{array}$ & $\begin{array}{l}\text { Open } \\
(20)\end{array}$ & $\begin{array}{l}\text { Covert dry } \\
\text { (36) }\end{array}$ & $\begin{array}{l}\text { Open } \\
(41)\end{array}$ \\
\hline $\begin{array}{l}\text { Temperature } \\
(\mathrm{P}>0.001) * * *\end{array}$ & $25.19 \pm 2.42 \mathrm{a}$ & $35.16 \pm 1.77 b$ & $40.57 \pm 0.66 \mathrm{c}$ & $39.9 \pm 3.40 \mathrm{c}$ & $51.10 \pm 4.60 \mathrm{~d}$ \\
\hline $\begin{array}{l}\text { Hygrometry } \\
(\mathrm{P}>0.001) * *\end{array}$ & $75.46 \pm 4.50 \mathrm{c}$ & $26.81 \pm 6.98 b$ & $17.14 \pm 9.97 \mathrm{a}$ & $\begin{array}{l}28.16 \pm \\
5.02 \mathrm{~b}\end{array}$ & $17.27 \pm 5.93 \mathrm{a}$ \\
\hline Antlions obtained & M. quinquemaculatus & $\begin{array}{l}\text { Myrmeleon sp } \\
\text { M. obscurus } \\
\text { Hagenomyia } \\
\text { tristis }\end{array}$ & M. obscurus & $\begin{array}{l}\text { M. obscurus } \\
\text { Sp indet } 2\end{array}$ & $\begin{array}{l}\text { C. bourbon } \\
\text { Cueta n. sp } \\
\text { Sp indet } 1 \\
\text { Sp indet } 2\end{array}$ \\
\hline
\end{tabular}

Variations in the density of antlion larvae are directly related to fluctuations in climatic parameters such as temperature, luminosity and relative humidity. However, it is clear that antlions in a humid environment prefer temperatures above $18^{\circ} \mathrm{C}$ and a mean sunshine below 45000Lux and a relative humidity above $45 \%$. As far as the larvae of the fresh canopy living under the trees are concerned, they prefer temperatures between $30^{\circ} \mathrm{C}$ and $42^{\circ} \mathrm{C}$ and a relative humidity lower than $45 \%$ and higher than $25 \%$ with a light intensity higher than 45000 Lux. For the larvae of the open environment their activities are best carried out at temperatures above $42^{\circ} \mathrm{C}$, a relative humidity below $25^{\circ} \mathrm{C}$ and a light intensity above 65000Lux. Therefore, higher or lower values of climatic parameters such as temperature, relative humidity and light intensity inhibit the activities of antlion larvae in their natural environment. These results are coherent with the work of Maogé et al., (2014) who showed that the hottest periods of the year correspond to the high density of pits of antlion larvae in the northern regions of Cameroon. The recorded climatic parameters and the distribution of larvae in the different sites show that not all antlions live in habitats with the same characteristics. The major characteristics: open (unprotected from rain, direct sunlight, etc.) (Barkae et al., 2012), covered (protected from rain, disturbance, direct sunlight, etc.) (Abraham, 2006; Adar et al., 2016; Klokocovnik et al., 2016) give a first idea of the larval habitats taking into account the relative humidity factor and sun exposure. This is not sufficient to qualify a species, because the position of a species in a habitat depends on the area and the seasons of the same area, this is the case with $M$. obscurus which lives in open habitat at the beginning of the dry season in the Sudano-Guinean zone, whereas during the warmest months it occupies the covered habitat and the same observations have been made in the Sudano-Sahelian zone with Sp Indet 2. Similarly, the presence of Cueta $s p$. larvae obtained in February 2016, the warmest year in the open environment of the Sudano-Guinean zone, sufficiently indicates that temperature and light intensity are two very important parameters to characterize the larvae 
habitats. It is noted that three habitats with different characteristics are present in the study area: (i) open environments which receive no shade all day long with maximum luminosity (94380.2 Lux), the highest temperatures $\left(51.10^{\circ} \mathrm{C}\right)$ and the driest soil $(17.27 \%$ hr), which is habitat by species of the genus Cueta. These conditions are only achieved during the harsh periods of the dry season in the Sudano-Sahelian zone. (ii) Covered and dry and/or cool open environments which are generally the shadows of trees in the Sudano-Sahelian zone at all times, in the SudanoGuinean zone in March and April. They are also encountered in the open environment of the SudanoGuinean zone at the beginning of the dry season. They are characterized by an average luminosity $(36124,2$ Lux), hygrometry which is characteristic of fresh environments, the rather average temperature inhabited by the species of the Tribe of Myrmeleontini except M. quinquemaculatus. (iii) Covered and humid environments with low luminosity (1311.25 Lux), low temperatures $\left(25.19^{\circ} \mathrm{C}\right)$ and fairly high relative humidity $(57.159 \% \mathrm{hr})$. Conditions which are close to the average annual conditions for the Sudano-Guinean zone, allow the survival of the species that are controlled by them all year round, namely $M$. quinquemaculatus. These conditions are those found in sheds, close to houses and in various places where rain does not fall directly all year round.

Conclusion: It exists a specific habitat for each antlion sampled. Larvae of the genus Cueta, occur in warm, dry and luminous conditions within arid Sahelian climate. Those of M. quinquemaculatus are frequently collected at permanent shade all the year round within humid Sudanian climate. Theoretically, according to their thermal preferences, these 2 antlions could not coexist. Occurrence of $C$. bourbonni in the moisty Soudano Guinean zone indicates episode of warming observed during the year 2016.

Acknowledgements: The authors of this article are grateful to Dr André Prost (Museum of Natural History, Paris, France) for the identification of this antlion, to Professor Roberto Pantaleoni (Institute of Agronomy, University of Sassari, Italy) for the bibliography offered and his advice for the breeding of these insects, to Professor EDOUNG of the University Institute of Technology of the University of Ngaoundéré for having constructed rearing cages hosting a sensor system allowing rearing of the larvae a fixed and controlled temperatures.

\section{REFERENCES}

Abraham, L. (2006). Pit building ant-lion larvae effect to the distribution of the substrate particle in their microhabitats. Natura Somogyensis Koposvar 9: 167-185

Adar, S; Dor, R; Scharf, I (2016). Habitat choice and complex decision making in a trap-building predator. Behav. Ecol. 27: 1491-1498.

Bakoidi, A; Djibo, I; Dobo, F; Maoge, J; Tinkeu, LSN (2018). Identification of the Optimum Temperature of Myrmeleon obscurus (Rambur, 1842). Entomol Ornithol Herpetol 8: 216.

Barkae, ED; Scharf, I; Subach, A; Ovadia, O (2010). The involvement of sand disturbance, cannibalism and intra-guild predation in competitive interactions among pit building antlion larvae. Zool. 113: 308-315.

Barkae, E D; Scharf, I; Abramsky, Z; Ovadia, O (2012). Jack of all trades, master of all: A positive association between habitat niche breadth and foraging performance in pit-building antlion larvae. PLoS One, 7, e33506.

Bowler, DE; Benton, TG (2005). Causes and consequences of animal dispersal strategies: relating individual behaviour to spatial dynamics. Biol. Rev. 80:205-225.

Clobert, J; editor (2012). Dispersal ecology and evolution. Oxford: Oxford University Press. 230 242.

Devetak, D; Novak, T; Janžekovic, F (2012). Effect of substrate density on behavior of antlion larvae (Neuroptera: Myrmeleontidae). acta oecol. 43: 17.

Djoufack Manetsa, V; Brou, T; Fontaine, B; Tsalefac M (2011). Variabilité intra saisonnière des précipitations et de leur distribution : impacts sur le développement du couvert végétal dans le Nord du Cameroun (1982-2002). Sécheresse, 22 :159170.

Dubois, Y; Blouin-Demers, G; Shipley, B; Thomas, D (2009). Thermoregulation and habitat selection in wood turtles Glyptemys insculpta: chasing the sun slowly. J. Anim. Ecol. 78:1023-1032.

Fotsing, E (2009). SMALL Savannah. Un Système d'Information pour l'analyse intégrée des changements d'utilisation de l'espace à l'Extrême Nord du Cameroun. PhD thesis, University of Yaoundé I, p.376. 
Klokocovnik, V; Devetak, D; Orla ` cnik, M (2012). Behavioral plasticity and variation in pit construction of antlion larvae in substrates with different particle sizes. Ethol, 118: 1-9.

Klokocovnik, V; Hauptman, G; Devetak, D (2016). Effect of substrate temperature on behavioural plasticity in antlion larvae. Behav. 153, 31-48.

Maogé, J; Ngamo Tinkeu, LS; Michel, B; Prost A., (2014). Spatial distribution of the pit builders antlion's larvae (Neuroptera: Myrmeleontidae) in the septentrional regions of Cameroon (Central Africa). IJRSP, 4: 1-10.

Morrison, LW (2004). Spatiotemporal variation in antlion (Neuroptera: Myrmeleontidae) density and impacts on ant (Hymenoptera: Formicidae) and generalized arthropod foraging. Ann. Entomol. Soc. Am., 97: 913-922.

Ngamo Tinkeu LS; Maogé, J; Aminatou Boubakary, AB (2010). Predation of Myrmeleon obscurus Navas 1912 (Neuroptera: Myrmeleontidae) on the ground ant Myrmicaria opaciventris EMERY (Formicidae : Myrmicinae). IJBCS. 4 (2): 509-514.

Ngamo Tinkeu, LS; Maogé, J (2014). Chetae of larva of antlions (Neuroptera: Myrmeleontidae) Hagenomyia tristis Walker 1853 and Myrmeleon obscures Rambur 1842 involve in the construction of pitfall traps. JBES. 5(4): 511- 519.
Ngamo Tinkeu, L S; Maogé, J; Koda, T (2016). Diversity of pit building ant lions (Neuroptera: Myrmeleontidae) and their potential preys in the sudano Guinean zone of Cameroon. JEZS, 4(1): 198202.

Scharf, I; Subch, A; Ovadia, O (2008b). Foraging behaviour and habitat selection in pit-building antlion larvae in constant light or dark conditions. Anim. Behav.76: 2049-2057.

Scharf, I; Filn, I; Ben-Yehoshua, D; Ovadia, O (2009). Phenotypic plasticity and variation in morphological and life-history traits of antlion adults across a climatic gradient. Zool. 112: 139150 .

Scharf, I; Luin, Y; Ovadia, O (2011). Foraging decisions and behavioural flexibility in trapbuilding predators: a review. Biol. Rev. 86: 626639.

Tchotsoua M.,Gonne B., (2010). Des crises socioéconomiques aux crises environnementales sur les hautes terres de l'Adamaoua, Cameroun. Savanes africaines en développement : innover pour durer, Cirad, 9 p. 